\title{
Children Early Mathematics Development Based on a Free Play Activity
}

\author{
Roslinda Rosli, Teo Wei Lin \\ Center of Innovation in Teaching and Learning, The National University of Malaysia (UKM), Bangi, Malaysia \\ Email: roslinda@ukm.edu.my, vivianwlteo@hotmail.com
}

How to cite this paper: Rosli, R., \& Lin, T. W. (2018). Children Early Mathematics Development Based on a Free Play Activity. Creative Education, 9, 1174-1185. https://doi.org/10.4236/ce.2018.97087

Received: May 7, 2018

Accepted: June 24, 2018

Published: June 27, 2018

Copyright $\odot 2018$ by authors and Scientific Research Publishing Inc. This work is licensed under the Creative Commons Attribution International License (CC BY 4.0).

http://creativecommons.org/licenses/by/4.0/

\begin{abstract}
Learning early mathematics is essential as it acts as a basis to young children in understanding higher mathematical concepts in the future. This paper discusses the learning of early mathematics through play activities that are widely integrated into the fields of education and psychology to describe how children acquire knowledge from their surroundings. Origami, singing, and construction blocks are part of play activities in preschool where teachers can utilize for basic mathematics development. The experiences relating to actual items or objects with quantity and quality such as color, sizes, and shapes before continuing to pictorial and symbolic stages will help to nurture children understanding of early mathematics.
\end{abstract}

\section{Keywords}

Preschool Kids, Kindergarten, Learning Number, Fun Learning, Learning through Play

\section{Introduction}

An educational curriculum involves learning programs within or outside the classroom, activities, equipment, planning, timetables, knowing subjects and the evaluation process (McKimm, 2003). The curriculum does not only focus on the learning experiences in school, but it also encompasses every moment in their daily lives, be it in the nursery, at home or outside (Kernan, 2007). Robinson (2004) stated that specialists from the Early Childhood Unit of National Children Bureau, United Kingdom believes that the curriculum for young children placed under care centers includes the following items:

- All learning development opportunities available to the children

- All activities, attitudes, and behavior, whether planned or not, either encour- 
aged or prohibited

- Methods on how the physical environment surrounding the children is arranged and also the daily routines of the adults or children themselves.

- The role adults play to organize, lead, influence and participate together in their children's activities.

- The involvement of parents in the matters mentioned.

Preschool education is an early preparation towards formal education that should attract and sow seeds of love for knowledge and schooling within children at initial level (Ali \& Mahamod, 2015). It is a crucial experience for children as useful, meaningful and enjoyable learning experiences that equip children with skills, confidence, and positivity as preparation for formal and lifelong education (Chin \& Zakaria, 2015; Samuelsson \& Kaga, 2008). It is a basis for children before they enter schools where it is the earliest education in the development of an individual's life after home education. Therefore, pre-school teachers should possess extensive knowledge regarding preschool education which comprises of children's development aspects, teaching and learning strategies, preschool administration centers and other aspects related to preschool education (Nasri, Halim, \& Ghani, 2018; UNICEF, 2008). Preschool education programs expose children to knowledge, skills, and values to children practically in an enjoyable atmosphere through the approach of play while learning. This approach is a flexible, dynamic, comprehensive, interactive and involving a method in classroom activities which emphasizes exploration and encourages curiosity among children (Samuelsson \& Kaga, 2008).

Learning early mathematics is essential as it acts as a basis for young children in understanding higher mathematical concepts in the future (Bakar, 2017). Knowledge of early mathematics obtained through direct and meaningful experiences in an enjoyable environment assists in cultivating the interest of students in learning mathematics (Ginsburg et al., 2008). Concepts such as pre-numbers, early numbers, number operations, measurements, shapes, time and spaces should be learned following the students' development stages and are important components in learning early mathematics in preschools.

\section{Free "Play" and Learning}

A play is a natural activity and a necessity for every child. They learn and discover through play activities because of their vast imagination (Morrison, 2000) and also during their infant days where they tend to manipulate their own body (Piaget, 1962). The play is a symbolic and meaningful activity and meaningful, where children are actively free to explore and discover their surroundings while enjoying but abiding by the rules of the game set by themselves (Montessori, 2007). Parents, teachers, kindergarten or nursery operators and communities should ensure children have significant time to learn by playing during their preschool. Play activities are a natural need in children's lives where they can explore, discover, inquire and construct through direct natural experience 
(Mielonen \& Paterson, 2009).

The term learning through play is widely used in the fields of education and psychology to describe how children acquire knowledge from their surroundings for learning (Puteh \& Ali, 2013). This approach is student-centered and relies on play activities throughout the teaching and learning process. Bazdis (2008) states that learning through play is the most appropriate curricular approach for children because this approach relates to the natural characteristics of children who enjoyed playing. Hence, the implementation of this approach should take into account the needs and interests of students where teachers guide and support their students during the play activities (Marouf, Che-Ani, \& Tawil, 2015).

The importance of learning through play receives recognition from scholars of early childhood education and psychologists such as Jean Piaget, Maria Montessori, Lev Semanovich Vygotsky, Jerome Bruner and Eric Erikson. They stated that play is an activity and games are the learning objects. Based on the Piaget's theory, most children in the preschool age (two to seven years old) are at their preoperational level where children learn to understand concepts through playing with objects (Piaget, 1962). Concept understanding involves children building their ideas and principles where it allows children to understand abstract concepts through concrete learning experiences without feeling pressured.

Since playing is considered to be part of a student's childhood, the process of teaching and learning can be more effective if the educational curriculum is play-based. Play activities enable children to learn and understand the issues surrounding them in an exciting yet meaningful way. Many scholars in early childhood development believed that play activities trigger the growth of social, physical, cognitive and emotional in our children's minds (Seifert, 2004). It is during these activities that children can communicate and interact with adults and peers through communications and discussions. They can also gradually adapt to the foreign environment through play activities (Goldstein, 2012).

From the psychoanalysis aspect of Freud, play activity provides children with opportunities to gain a sense of control over situations said to help children deal with reality (Gray, 2013). Freud stated in his theory that play is essential for children because it enables them to express their views (Gray, 2013). The approach does not utilize any activity without planning but the elements such as planned play, flexible, and structured play that fulfills cognitive, psychomotor and affective needs. The play activity usually involves physical movement for the children psychomotor skills and self-awareness development. Children will feel excited, happy and active in carrying out these activities, allowing them to develop skills that encourage them to explore secure, confident and independent (Moylett \& Stewart, 2012).

According to National Association for the Education of Young Children ([NAEYC], 2009), learning early mathematics begins with a discovery of materials such as constructing blocks, building a sand castle, and measuring water. Also, learning mathematics through play-based activity should enable children 
to use mathematics as a tool to explore, discover and problem-solving. Mathematical ability is the essential skill needed for everyday life (Cragg \& Gilmore, 2014).

In many countries, the preschool education program is for children between the age of four to six years old in preparing them for daily life situations and adapting the incoming primary education (Hewitt, 1998). This preschool curriculum is implemented using various approaches including play while learning, integrated and themed plan and also the use of ICT but all procedures emphasize the involvement of fun activities. The importance of the play activity in early childhood education, especially during preschool, requires a teacher to facilitating these activities for building children interest in learning mathematics (Sheridan et al., 2009). As such, parents and teachers should work together in creating an environment filled with love and can stimulate the minds of children, both mentally and physically.

One of the better examples of a nation implementing play-based learning in their preschool curriculum in Japan. According to Sakakibara (2014), Japanese preschools or known as "play" schools where the children of Japan are not taught academic until they reach the age of seven. Only a small portion of parents send their children for private education such as Kumon where the children would learn academically. If not, preschool education is to instill independence, discipline, interactions, creativity, play, swimming, painting and much more. Japanese children are ready mentally to learn academic only when they enter primary schools. Japanese preschools emphasize more on the social-emotional part of education. Japanese children participate in free play activities most of the days and parents are encouraged to interact with them mathematically in real life, such as counting down elevator numbers with only a few parents discussing workbooks (Murata, 2004). For example, origami is the art of folding paper can be used to teach mathematics extensively. By using arranged conditions, teachers allow students to manipulate materials given to them and share the outcome with the rest of the class. Hence, in Japanese schools and homes, these activities are regular activities that show the Japanese do not neglect the importance of mathematics during preschool.

\section{Preschool Mathematics}

The essential mathematical development among children begins from their experiences related to real items or objects that have quantity or qualities such as different colors, sizes, and shapes while manipulating the numbers in their surroundings. According to Piaget (1962), every normal child is capable of understanding mathematics well when activities and methods used can attract their interest. Mathematics is an example of logical thinking that shapes the number concept among children that requires experience, social interaction, time, language and understanding of the children's thoughts.

According to Ojose (2008), mastery of mathematical concepts does not come 
from workbooks or assignments or paper and pen. Children construct their mathematics knowledge and develop mathematical skills through hands-on experience with real-life activities. Children will use their mathematical thinking in solving actual problems in building the mathematical abilities. Children master their cognitive skills through real interactions using the various materials found in their surroundings. Play activity is a valuable yet straightforward for children (Md. Noor, 2003). However, the understanding of the concept of playing in the educational context remains vague among educators and early childhood education curriculum practitioners.

Although play activities in preschool can attract children's interest in learning mathematical skills and concepts in the early stages, yet there are not many teachers who would emphasize play while learning in preschools (Christie \& Roskos, 2009). A study by Chervenak (2011) that reports on the teacher's perspective on play-based learning found that most respondents agreed on the importance of integrating play in the curriculum. However, to fulfill the minimum standards, teachers rarely have sufficient time to organize play activities in classes. Miller and Almon (2009) state that many teachers are still ignoring the play approach in preschools due to the pressure of achieving academic performance and learning standards. Most parents exert stress on their children since young as to focus more on academics and less on playing (Essa, 2011).

In the case of Japanese preschool teachers, they are different from the primary teachers in the sense that they emphasize more on emotional and social growth. Instead of teaching mathematics directly to the students, they use tools and materials such as scoreboards to write numbers and card games to encourage quantitative thoughts from the students (Hatano \& Sakakibara 2004). Furthermore, they improve this activity by asking the children or joining in the children's activities. The teachers would invite the students who possess a better understanding of lessons to share their thoughts so to stimulate other children's thinking (Hatano \& Sakakibara 2004). Since Japanese culture values highly of mathematical concepts and skills, these activities often occur in the children's daily lives.

\section{Free Play-Based Activities in Learning Mathematics}

\subsection{Origami}

There are various activities of learning mathematics in the form of play such as origami. The Japanese art of paper folding, origami is derived from the Japanese word "ori" meaning folded and "gami" means paper (Ramirez, 2015). Origami, though often associated with Japanese culture, has been inherent throughout the world. The art of paper folding into different shapes and sizes is also known as Paper Crane in western countries. The art of paper folding has been popular since the Edo period (1603-1867), but in the modern era, origami has evolved to be an innovation to creating intricate patterns without any cutting of the paper (Sakamoto \& Okada, 2013). There are also innovative creations where the origami shapes are capable of movement by adding elements of electronics. 
As such, it is no surprise that origami is incorporated in the learning process in preschools all over the world not only as a creative activity for children but also because origami involves the cognitive, affective and motor skills of children and can spur their knowledge understanding of space and area (Brady, 2008). Many benefits can come from the art of paper folding, especially in the field of mathematics. As preschool students often face difficulties in understanding both formulas and applications of mathematics, origami can be very beneficial to them, especially while learning geometry. Through origami, children can solve mathematical problems in a structured and systematic way while having fun (Oguz, 2016). According to Ramirez (2015), origami can enhance different mathematical skills among children. The National Center for Education Statistics (2003) states one of the weaker areas of mathematics among students is geometry. Incorporation of origami in the learning activities showed positive results in increasing the understanding of formulas, labels and geometrical concepts among children while elevating their interest in studying. Also, origami triggers students' thinking skills and other learning modalities where this art of paper folding has shown improvement of spatial visualization skills among children through hands-on experience (Ku \& Jie, 2012). Such capabilities help children to understand, characterize, and build their comprehension to their surroundings.

Fractional operations and concept is another topic feared by most students. With origami, fractions can be demonstrated in a tactile and touchable way. Origami can be used in lessons to indicate fraction concepts such as one-half, one third or one-quarter by (Figure 1) merely folding the paper into the shapes desired (Huang, 2012). The idea of infinity can also be performed by continuously folding the paper. Besides that, origami also helps improve children's problem-solving skills where children are required to solve problems based on trial and error attempts (Koning \& Tabbers, 2011). Preschool teachers can come up with a random shape and request the children replicate the configuration shown; there are multiple solutions in getting the required shape or pattern, and there is no wrong answer.

Research has shown that children who utilize the concepts of origami perform better in mathematics as it is often used to assist in mathematical lessons such as geometry and algebra while increasing children's manual dexterity (Brady, 2008). Origami can prove to be fun and addictive yet challenging depending on the complexity of its patterns. The fact that origami poses no age limits for its
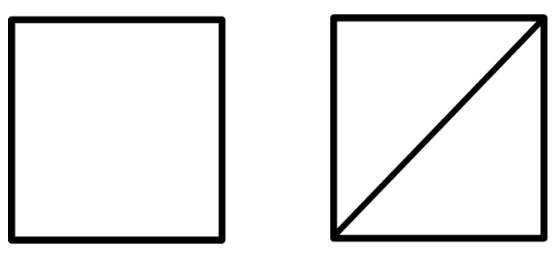

One fold

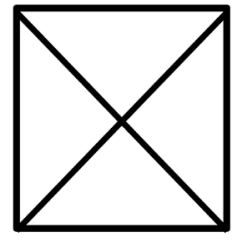

Two folds

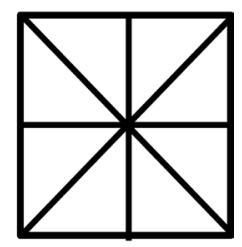

Four folds

Figure 1. Fraction through paper folding. 
users, ranging from children to adults, adults can sharpen their creativity and improve their concentration while children can enjoy learning mathematics in a different way (Ramirez, 2015). Through the full range of knowledge and skills involved in this art of paper folding, origami is expected to provide an added value of competency and durability of its users in this competitive world.

\subsection{Construction Blocks}

Suitable selection of games for children during their learning stage is essential for the positive development of their minds, social skills, physical and creativity (Chin \& Zakarian, 2015; Goldstein, 2012). Children can learn to be more innovative and think smart through free "play" activities. Besides origami, construction blocks (Figure 2) are also often used in developing mathematics skills among children due to its popularity among children and are economically efficient. Block games, although not as sophisticated as other mathematics games available, yet is very suitable to be used as a tool to stimulate children's development as a whole. These building blocks that come in various shapes, sizes and colors can be manipulated by children and parents to stimulate young minds during the early age of learning and schooling of children (Guyton, 2011).

The flexibility of this activity allows children's imagination to run wild by diversifying methods of playing. Children not only learn shape building using the blocks, but they will also understand the concept of balance, mathematical concepts, constructing skills and even problem-solving skills (Drew et al., 2008). Socially, block games encourage children to be more active in working together as a group with their friends (Lynch \& Simpson, 2010). A game using building blocks can be the first experience for younger children to play in a group while for older children, it educates them about the importance of solving a problem together.

Block games also help children in their physical development when they handle, arrange, and match respective blocks to build a specific structure (ECA Council, 2003). The activity makes their grip strength and also enhances their eye-to-hand coordination. Besides that, block games help preschool children learn various mathematical concepts such as addition, subtraction, multiplication, and division. For younger children, they will learn vocabulary, such as color, size, shape, and position while for children in schools, they discover the concepts of gravity, geometry, and balance. Block games also provide an opportunity for children to build structures according to their imagination (Goldstein, 2012). They would be able to experience the satisfaction of creating their inventions.

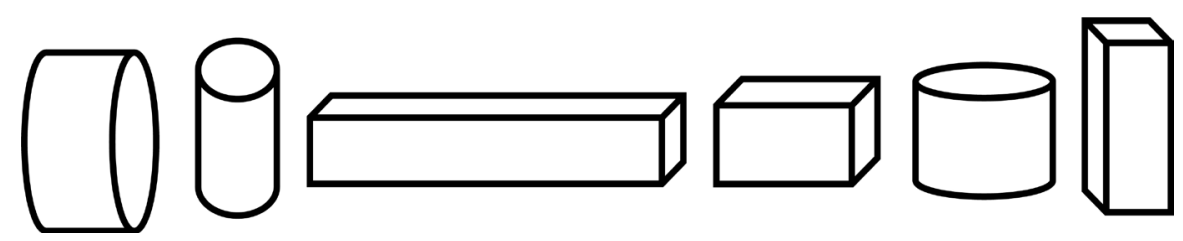

Figure 2. Toy blocks. 
Parents should also request for their children to explain about their creations to increase the children's creativity. Block games are games that are beneficial for children's development of all levels and stages of life from infancy to schooling stage. Block games also help in developing children holistically with the participation of their parents, understanding and encouraging them in the process of the games.

\subsection{Singing and Music}

Mathematics is always a complex and challenging subject among young children, but this perception can move away if teachers play a different pace from the usual lessons. The trick in teaching mathematics in preschools is to have each experience as motivated, creative and enjoyable as it can be. Another method that preschool teachers can adopt in teaching mathematics to children is through the technique of singing or musical accompaniment lessons. Research shows that children were learning faster and more efficient when teachers used rhythms and specific paces in songs and chants (Neila, 2013). Hence, the integration of singing and music is a meaningful activity for children to explore mathematical concepts while improving their language and hearing through music.

There is a long-term and robust connection between mathematics and music, primarily during children's preschool stage (Awopetu Anna, 2016). What makes it even more exciting is that young children have been learning about mathematics unknowingly during their childhood movement and music classes. One of the mathematical skills learned through music is geometry where children develop the essential basis on geometry through dances, playing instruments and moving around in a pattern. Movements that have a specific model such as "front and back" and "in and out" help raise the spatial-temporal reasoning skills and spatial awareness among children that are essential for the children's foundation in mathematics (Deasy, 2002). Besides that, children can also find patterns in mathematics and music. Kenney (2005) states that young kids may develop the ability to understand and manipulate models from simple chants and rhymes. Listening to sections of music allows children to identify different parts of the music. This in-turn enables children to understand better when they are given mathematics patterns during lessons. Also, there are also plenty of children's counting rhymes, number songs and finger plays that can be part of the child's early childhood mathematics curriculum. Counting steps in dance and playing musical instruments expose children to both music and mathematics concepts in their early stages of learning. For example, the lyric of Once I Caught a Fish Alive song represents a counting rhyme for young children learning about numbers.

One, two, three, four, five

Once I caught a fish alive,

Six, seven, eight, nine, ten,

Then I let it go again. 
Why did you let it go?

Because it bit my finger so.

Which finger did it bite?

This little finger on my right.

(Count from 1 to 10 )

One, two, three, four, five,

Once I caught a fish alive,

Six, seven, eight, nine, ten,

Then I let it go again.

It is clear that the existence of music at home and in the classroom is essential to the understanding of the importance of patterns in mathematics, daily learning experiences and the need of stimulating learning environment. Children often interact with models and numbers unknowingly through music as music is a suitable way for young children to engage in mathematics learning socially and naturally (Okongo, 2007).

\section{Conclusion}

A stimulating environment to encourage learning while playing in preschools is vital. Therefore, to ensure the effectiveness of learning mathematics, teachers must acknowledge different culture and needs from various groups of children. Teachers should also realize that managing a classroom requires the ability to do multiple things at one time, to make essential decisions immediately daily and also to adapt and be flexible to sudden changes. Mathematics is an abstract and complex concept, thus meaningful learning through play activity for nurturing young children's interest and attitude towards mathematics should be the focus of the preschool curriculum. Teachers must avoid personal emotions during their interactions with young children as the education field is quite minded challenging considering the various play activities to be organized and accomplished. In the end, teachers should always take extra care of their progress and professionalism development as the children's role models.

\section{References}

Ali, A., \& Mahamod, Z. (2015). Development of Play-Based Instruction Module for Teaching Preschoolers' Language Skills. Australian Journal of Basic and Applied Sciences, 9, 110-118.

Awopetu Anna, V. (2016). Musical Activities as a Stimulating Tool for Effective Early Year's Education of a Whole Child. International Journal of Education and Research, 4, 53-64.

Bakar, K. A. (2017). Young Children's Representations of Addition in Problem Solving. Creative Education, 8, 2232-2242. https://doi.org/10.4236/ce.2017.814153

Bazdis, M. (2008). Pendidikan anak-anak di peringkat awal umur berasaskan binaan kurikulum yang integratif. Jurnal Pusat Penyelidikan Perkembangan Kanak-kanak Negara (NCDRC). Universiti Pendidikan Sultan Idris. Malaysia. 
Brady, K. (2008). Using Paper-Folding in the Primary Years to Promote Student Engagement in Mathematical Learning.

Chervenak, R. (2011). Play in Kindergarten: Perspectives a Full- and Half-Day Kindergarten Teacher. https://etd.ohiolink.edu/!etd.send_file?accession=bgsu1307916817\&disposition=inline

Chin, L. C., \& Zakaria, E. (2015). Understanding of Number Concepts and Number Operations through Games in Early Mathematics Education. Creative Education, 6, 1306-1315. https://doi.org/10.4236/ce.2015.612130

Christie, J. F., \& Roskos, K. A. (2009). Play's Potential in Early Literacy Development. Encyclopedia on Early Childhood Development. Centre of Excellence for Early Childhood Development.

http://www.childencyclopedia.com/documents/Christie-RoskosANGxp.pdf

Cragg, L., \& Gilmore, C. (2014). Skills Underlying Mathematics: The Role of Executive Function in the Development of Mathematics Proficiency. Trends in Neuroscience and Education, 3, 63-68. https://doi.org/10.1016/j.tine.2013.12.001

Deasy, R. J. (2002). CriticallLinks: Learning in the Arts and Student Academic and Social Development.

https://www.gpo.gov/fdsys/pkg/ERIC-ED466413/pdf/ERIC-ED466413.pdf

Drew, W. F., Christie, J., Johnson, J. E., Meckley, A. M., \& Nell, M. L. (2008). Constructive Play: A Value-Added Strategy for Meeting Early Learning Standards. Young Children, 63, 38-44.

Early Childhood Advisory (ECA) Council (2003). Guidelines for Preschool Learning EXperiences. Massachusetts Department of Education.

Essa, E. L. (2011). Introduction to Early Childhood Education (6th ed.). USA: Wadsworth, Cengage Learning.

Ginsburg, H. P., Lee, J. S., \& Boyd, J. S. (2008). Mathematics Education for Young Children: What It Is and How to Promote It. Social Policy Report: Giving Child and Youth Development Knowledge Away, 22, 1-23.

Goldstein, J. (2012). Play in Children's Development, Health, and Well-Being. Brussels: Toy Industries of Europe.

Gray, P. (2013). Play as Preparation for Learning and Life. American Journal of Play, 5, 271-292.

http://www.journalofplay.org/sites/www.journalofplay.org/files/pdf-articles/5-3-intervi ew-play-as-preparation.pdf

Guyton, G. (2011). Using Toys to Support Infant-Toddler Learning and Development (pp. 50-56).

Hatano, G., \& Sakakibara, T. (2004). Commentary: Toward a Cognitive-Sociocultural Psychology of Mathematical and Analogical Development. In L. D. English (Ed.), Mathematical and Analogical Reasoning of Young Learners (pp. 187-200). Abingdon-on-Thames: Routledge.

Hewitt, B. L. (1998). Parental Perceptions of Pre-School Education in Malaysia. http://ro.ecu.edu.au/cgi/viewcontent.cgi?article=1975\&context=theses

Huang, Y. (2012). Easigami: Virtual Creation by Physical Folding (p. 62). Computer Science Graduate Theses \& Dissertations.

http://scholar.colorado.edu/cgi/viewcontent.cgi?article=1058\&context=csci_gradetds https://doi.org/10.1145/2148131.2148143

Kenney, S. (2005). Nursery Rhymes: Foundation for Learning (pp. 28-31). General Music Today, Fall 2005. https://doi.org/10.1177/10483713050190010108 
Kernan, M. (2007). Play as a Context for Early Learning and Development. Dublin: National Council for Curriculum and Assessment.

Koning, B. B., \& Tabbers, H. K. (2011). Facilitating Understanding of Movements in Dynamic Visualizations: An Embodied Perspective. Educational Psychology Review, 23, 501-521. https://doi.org/10.1007/s10648-011-9173-8

Ku, J., \& Jie, Q. (2012). Introduction to Origami Folding, Design and Analysis. In Proceedings of the 6th International Conference on Tangible, Embedded and Embodied Interaction (pp. 383-384). https://doi.org/10.1145/2148131.2148224

Lynch, S. A., \& Simpson, C. G. (2010). Social Skills: Laying the Foundation for Success. Dimensions of Early Childhood, 38, 3-12.

Marouf, N., Che-Ani, A. İ., \& Tawil, N. M. (2015). Examining Physical Activity and Play Behavior Preferences between First Graders and Last Graders in Primary School Children in Tehran. Asian Social Science, 12, 17. https://doi.org/10.5539/ass.v12n1p17

McKimm, J. (2003). Curriculum Design, and Development. http://www.faculty.londondeanery.ac.uk/e-learning/setting-learning-objectives/Curric ulum_design_and_development.pdf

Md. Noor, M. (2003). Kepentingan bermain dalam pendidikan prasekolah. https://www.scribd.com/document/4007899/Kepentingan-Bermain-Dalam-Pendidikan -Prasekolah

Mielonen, A. M., \& Paterson, W. (2009). Developing Literacy through Play. Journal of Inquiry \& Action in Education, 3, 15-46.

Miller, E., \& Almon, J. (2009). Crisis in Kindergarten: Summary and Recommendations of Why Children Need to Play in School. A Report from Alliance. http://earlychildhoodcolorado.org/inc/uploads/Crisis_in_Kindergarten.pdf

Montessori, M. (2007). Early Childhood Programs: Applying Theories to Practice. Early Childhood Education Today. Upper Saddle River, NJ: Prentice Hall, Inc.

Morrison, G. S. (2000). Early Childhood Education Today. Upper Saddle River, NJ: Prentice Hall, Inc.

Moylett, H., \& Stewart, N. (2012). Development Matters in the Early Years Foundation Stage. London: Early Education.

https://www.officreche.com/images/Development\%20Matters\%20in\%20the\%20EYFS.p df

Murata, A. (2004). Paths to Learning Ten-Structured Understanding of Teen Sums: Addition Solution Methods of Japanese Grade 1 Students. Cognition and Instruction, 22, 185-218. https://doi.org/10.1207/s1532690xci2202_2

Nasri, N., Halim, L., \& Ghani, A. K. A. (2018). Malaysian Science Teacher Standard: Preliminary Framework. Journal of Advanced Research in Dynamical \& Control Systems, 10, 938-943.

National Association for the Education of Young Children (NAEYC) (2009). Developmentally Appropriate Practice in Early Childhood Programs Serving Children from Birth through Age 8.

http://www.naeyc.org/files/naeyc/file/positions/position\%20statement\%20Web.pdf

National Center for Education Statistics (2003). The Condition of Education 2003. https://nces.ed.gov/pubs2003/2003067.pdf

Neila, M. M. (2013). Using Songs in the ESL Classroom: A Reflexion and a Proposal. https://uvadoc.uva.es/bitstream/10324/4822/1/TFG-L383.pdf

Oguz, A. (2016). An Instructional Method Suggestion: Conveying Stories through Origami. Journal of Education and Training Studies, 4, 9-22. 
https://doi.org/10.11114/jets.v4i8.1573

Ojose, B. (2008). Applying Piaget's Theory of Cognitive Development Mathematics Instruction. The Mathematics Educator, 18, 26-30.

Okongo, B. C. O. (2007). Promoting Child Development through Music: A Comparison of Preschool Teachers' Perspective in Kenya and United States.

http://soar.wichita.edu/bitstream/handle/10057/2503/THESES2009_10.pdf?sequence=1

Piaget, J. (1962). Play, Dreams, and Imitation in Childhood. New York, NY: Nortan.

Puteh, S. N., \& Ali, A. (2013). Belajar melalui bermain: Prinsip utama kurikulum pendidikan awal kanak-kanak. Kuala Lumpur: Utusan Publications and Distributors Sdn. Bhd.

Ramirez, A. (2015). 5 Reasons Why Origami Improves Students'Skills. https://www.edutopia.org/blog/why-origami-improves-students-skills-ainissa-ramirez

Robinson, A. (2004). Working with Young Children Who Have Special Needs or Disabilities: A Guide to Sources of Information. London: Early Childhood Unit, National Children's Bureau.

Sakakibara, T. (2014). Mathematics Learning and Teaching in Japanese Preschool: Providing Appropriate Foundations for an Elementary Schooler's Mathematics Learning. International Journal of Educational Studies in Mathematics, 1, 16-26. https://doi.org/10.17278/ijesim.2014.01.002

Sakamoto, S., \& Okada, Y. (2013). Paper Analysis and Database of Papers of the Pelliot Collection Dunhuang Manuscripts. In Culture and Computing (Culture Computing) 2015 International Conference (pp. 203-204).

Samuelsson, I. P., \& Kaga, Y. (2008). The Contribution of Early Childhood Education to a Sustainable Society. Paris: UNESCO.

Seifert, K. L. (2004). Cognitive Development and the Education of Young Children. Handbook of Research on the Education of Young Children, Mahwah, NJ: Erlbaum.

Sheridan, S. M., Edwards, C. P., Marvin, C. A., \& Knoche, L. L. (2009). Professional Development in Early Childhood Programs: Process Issues and Research Needs. Early Education and Development, 20, 377-401. https://doi.org/10.1080/10409280802582795

UNICEF (2008). Children in Focus: Early Childhood Development. https://www.unicef.org/easterncaribbean/UNICEF_CIF.pdf 